\title{
ANALISIS PENGARUSUTAMAAN GENDER (PUG) DAN PERLINDUNGAN ANAK DI KABUPATEN LAMPUNG TENGAH
}

\author{
Annissa Valentina \\ Universitas Nahdlatul Ulama Lampung, Indonesia \\ Nisavalen26@gmail.com
}

\begin{abstract}
This study aim to map the gender gap and children protection problems in community local area considerated for Local Government create gender equality and children protection strategy and policy. The study was conducted in Central Lampung Region, Lampung, Southest Sumatera. Local Government should be sensitive of gender and children with take many efforts to contend those problem as Indonesian Government programme (PUG) and Children Protection to guarantee practical and strategical need for every people. The methodology used were surveys and document study. The results showed that women weren't understand fully yet about violent mentally, many parents didn't have any knowledge about child bring up model, and less of the public services and policy with good service standard. Besides, in government part, Lampung Tengah Government haven 't implement PUG and Children Protection yet into a legal act as political commitment, especially for Education and Health Sector. It just word or maybe hope.
\end{abstract}

Keywords : Central Lampung, Gender, Children, PUG, Protection

\begin{abstract}
ABSTRAK
Studi ini bertujuan memetakan masalah kesenjangan gender dan perlindungan anak dalam lingkungan masyarakat lokal agar pemerintah dapat menciptakan strategi dan arahan kebijakan yang berpihak pada kesetaraan gender dan terlindunginya hak anak. Studi dilaksanakan di Kabupaten Lampung Tengah, Provinsi Lampung, Sumatera Bagian terSelatan. Pemerintah seharusnya sensitif gender dan anak dengan melakukan upaya-upaya mengatasi kesenjangan gender untuk menjamin terpenuhinya kebutuhan praktis maupun strategis bagi segenap kalangan melalui PUG (Pengarusutamaan Gender) dan Perlindungan Anak menggunakan metode survei dan studi pustaka. Hasil penelitian menunjukkan bahwa perempuan belum memahami kekerasan mental karena hanya mengetahui kekerasan fisik, masih banyak orangtua yang belum memiliki pengetahuan pola asuh anak yang tepat, pelayanan kesehatan belum berstandar pelayanan bagi anak-anak sehingga hak anak belum terpenuhi, dan belum adanya komitmen politik pemerintah yang dituangkan dalam payung hukum yang jelas dalam implementasi PUG dan Perlindungan Anak di Kabupaten Lampung Tengah karena masih sebatas wacana.
\end{abstract}

Kata Kunci: Lampung Tengah, Gender, Anak, PUG, Perlindungan 


\section{PENDAHULUAN}

Isu mengenai gender dan anak telah lama menjadi masalah utama dalam pembangunan suatu negara, khususnya dalam pelaksanaan pembangunan. Pemerintah telah melakukan berbagai upaya untuk meningkatkan kualitas hidup perempuan dan anak serta penguatan kapasitas kelembagaan dalam hal pengarusutamaan gender dan anak. Pada kenyataannya, data masih menunjukkan bahwa terdapat kesenjangan dalam hal akses, partisipasi, manfaat, serta penguasaan sumberdaya, seperti halnya dalam bidang pendidikan, kesehatan, ekonomi, dan bidang strategis lainnya.

Tidak hanya di Indonesia, isu gender telah menjadi pembahasan secara global di mana terdapat fakta bahwa tak ada satu kawasan pun di negara-negara berkembang yang berlaku kesetaraan laki-laki dan perempuan dalam hak-hak hukum, sosial, dan ekonomi. Kesenjangan gender sudah terjadi begitu luas dalam hal akses dan kendali atas sumber daya, kesempatan ekonomi, kekuasaan, dan hak memberikan suaranya dalam politik. Meskipun perempuan dan anak perempuan menjadi pemikul langsung beban terberat dari ketidaksetaraan ini, beban itu akan diderita juga oleh masyarakat, dan pada akhirnya akan merugikan setiap orang*. Dalam berbagai kesempatan kerap perempuan sebagai selalu dijadikan objek eksploitasi, serta adanya upaya marginalisasi perempuan. Padahal bila ditinjau dari konteks kehidupan bermasyarakat, perempuan mempunyai hak yang sama dengan laki-laki untuk diperlakukan secara adil dalam berbagi peran di segala bidang kehidupan. Keprihatinan negara-negara di dunia telah diwujudkan dalam berbagai bentuk pertemuan yang menghasilkan serangkaian deklarasi dan konvensi dan telah dicatat dalam berbagai dokumen sejarah** .

Salah satu masalah kesenjangan gender yang masih terjadi di Indonesia, di antaranya adalah pada pasar kerja, di mana terdapat akses perempuan terhadap kesempatan yang mendatangkan pendapatan lebih rendah daripada akses laki-laki. Perempuan lebih kecil kemungkinannya untuk bekerja, dan sebaliknya lebih besar kemungkinannya untuk tidak dipekerjakan. Perempuan cenderung mendapatkan upah lebih kecil daripada laki-laki. Dalam kenyataan secara umum, sudah terjadi kemitraan peran laki-laki dan perempuan dalam kehidupan sehari-hari dengan tahapan kemitraan, yang berbeda-beda dari satu

\footnotetext{
* Bank Dunia dalam Buku Data Terpilah Gender

**Buku Data Terpilah Gender
} 
keluarga ke keluarga lainnya, dari satu daerah ke daerah lainnya. Kemitraan gender ini tercermin dalam akses dan kontrol terhadap sumberdaya keluarga, meskipun belum tercapai kesetaraan yang sempurna. Namun demikian, masih terjadi adanya ketimpangan gender atau ketidakseimbangan kemitraan gender yang sempurna di dalam tingkat masyarakat, yang dibuktikan dengan minimnya perempuan menduduki pengurus organisasi ekonomi, dan organisasi kemasyarakatan lainnya. Organisasi perempuan yang ada umumnya adalah organisasi keagamaan dan perkumpulan sosial.

Dalam hal ini, masih ditemui adanya kendala terhadap peran perempuan dalam berkontribusi pada kegiatan ekonomi dan sosial budaya. Belum terjadinya keseimbangan peran yang sempurna antara laki-laki dan perempuan, berkaitan dengan budaya masyarakat tradisional yang patriarkhi. Budaya tersebut menganggap bahwa laki-laki sebagai main/primary breadwinner, dan perempuan sebagai a secondary breadwinner (Herien Puspitawati).

Negara telah memberikan jaminan dalam hal persamaan hak dan kedudukan setiap warga negara, baik laki-laki maupun perempuan. Dalam Undang-undang Dasar 1945 pasal 27 ayat 1 dikemukakan mengenai adanya jaminan negara atas persamaan hak bagi setiap warga negara dalam hal hukum dan pemerintahan, pekerjaan dan penghidupan yang layak, usaha bela negara, dan dalam memperoleh pendidikan. Oleh karena itu, diperlukan sistem terpadu dan komitmen yang kuat dari semua pemangku kepentingan untuk dapat mengatasi isu kesenjangan gender dan anak.

Upaya dalam memperkecil kesenjangan gender dan anak yang terjadi pada sektor kehidupan, yakni melalui kebijakan dan program pembangunan yang dikembangkan saat ini dan mengintegrasikan unsur-unsur pengalaman, aspirasi, kebutuhan, dan permasalahan perempuan dan laki-laki dalam perencanaan, pelaksanaan, pemantauan, dan evaluasi pada seluruh kebijakan dan program pembangunan nasional ke depannya. Oleh karena itu, pemerintah telah menerbitkan Inpres Nomor 9 Tahun 2000 tentang Pengarusutamaan Gender dan Pembangunan yang mewajibkan seluruh departemen maupun lembaga pemerintah non departemen baik di skala pusat maupun daerah melaksanakan pengarusutamaan gender dalam kebijakan dan program yang berada di bawah tugas dan tanggung jawab masing-masing. 
Studi ini dilakukan di Kabupaten Lampung Tengah, pada masyarakat dan pemerintah daerah, baik Pemerintah Kabupaten Lampung Tengah dan Dinas Pendidikan dan Dinas Kesehatan. Penelitian dilakukan selama 4 bulan terhitung mulai Bulan Agustus sampai dengan Bulan November 2016. Hal yang diteliti mengenai pengarusutamaan gender dan perlindungan anak karena pemerintah Kabupaten Lampung Tengah yang harus dapat melakukan upaya-upaya dalam mengatasi kesenjangan gender untuk dapat menjamin terpenuhinya kebutuhan praktis maupun strategis bagi segenap kalangan. Selain itu, agar dapat menciptakan strategi dan arahan kebijakan yang berpihak pada kesetaraan gender dan terlindunginya hak anak, terutama dalam aspek pendidikan dan kesehatan.

\section{METODE PENELITIAN}

Studi ini didasari oleh survey dan riset kepustakaan dengan melihat realitas di lapangan, melakukan wawancara serta membagikan angket kemudian menelusuri varian sumber-sumber sekunder dalam teks tertulis berupa buku, makalah, artikel jurnal dan laporan-laporan yang relevan. Prosedur yang lazim digunakan yakni (1) Interview (Wawancara), (2) Kuesioner/Angket (3) Melakukan analisis (4) Mengajukan kesimpulan.

\section{HASIL DAN PEMBAHASAN}

\section{Masalah Pembedaan Gender}

Dalam masyarakat, orang-orang masih memiliki reaksi yang berbeda dalam memperlakukan orang lain sesuai dengan gendernya yang sangatlah berpengaruh terhadap caranya mengevaluasi dirinya serta pendapat tentang dirinya sendiri. Salah satu contohnya adalah sikap orang tua (parental attitudes), sikap yang hampir selalu direfleksikan dalam perilaku orang tua (parental behavior). Cepat atau lambat seorang anak akan merasakan atau mengetahui apakah ia (berdasarkan gendernya) anak yang diharapkan oleh orang tuanya, serta berdasarkan perubahan perlakuan yang diterimanya dari orang tuanya ataupun saudara-saudaranya. Hal ini akan tetap mempengaruhi sikapnya terhadap dirinya sendiri karena seseorang menginterpretasikan perilaku orang tuanya secara tepat atau keliru. Konsep diri seseorang juga akan dipengaruhi oleh perlakuan sikap saudara kandungnya terhadapnya. Jika pertentangan antar gender yang terjadi di dalam kelompok (sesama rekan sejawat) sangatlah kuat, maka reaksi seorang anak terhadap gendernya memiliki dampak yang kuat terhadap konsep dirinya. 
Bahkan sebelum berakhirnya masa balita, tekanan sosial sudah muncul dalam diri anak-anak, yakni berupa tuntutan untuk berperilaku sesuai dengan gendernya dan memandang dirinya sebagaimana pandangan masyarakat terhadap orang-orang yang bergender sama dengannya. Dalam proses pembentukan kepribadiannya, kelompok budaya, yang dimulai dengan keluarga, kemudian berkembang menjadi rekan sebaya dan masyarakat, memberikan peluang dan dorongan kepada seseorang untuk belajar berperilaku yang seharusnya (sesuai dengan gendernya). Namun sebaliknya, kelompok tersebut menghambat / menghalanginya untuk belajar berperilaku seperti lawan jenisnya.

Kegagalan dalam mengatasi permasalahan dalam mengembangkan sikap yang sehat terhadap diri sendiri dan juga terhadap orang lain yang bergender sama dapat menyebabkan ketimpangan dalam penyesuaian diri dan sosial. Pada saat seorang anak mencapai usia 4 tahun, bahkan pada umumnya sebelum usia tersebut, ia akan menyadari bahwa di dunia ini tidak saja terdapat dua jenis manusia (laki-laki dan perempuan) tapi juga terdapat label-label tertentu yang diberikan kepada mereka.

Di lingkungan rumah, terutama seorang ibu, akan bersikap lebih tegas kepada anak perempuannya. Remaja sangat memperhatikan standar ganda dari perilaku moral. Berdasarkan standar ini banyak hal yang dianggap "salah" bagi anak perempuan, namun tidak demikian bagi anak laki-laki, sementara hal apa pun yang dapat dilakukan oleh anak perempuan tidak akan dianggap sebagai hal yang salah bagi anak laki-laki. Standar ganda ini merupakan akibat dari besarnya otonomi yang diberikan kepada anak laki-laki pada segala usia. Baik laki-laki ataupun perempuan akan menginterpretasikan hal ini sebagai keyakinan orang tua bahwa anak laki-laki lebih mampu menghadapi pergaulan sosialnya dibanding anak perempuan. Selain itu anak perempuan juga menemukan fakta bahwa mereka tidak diterima dalam fungsi sosial apapun, kecuali disertai / didampingi oleh anak laki-laki, sementara anak laki-laki dapat diterima dalam kondisi apa pun. Hal ini memberikan petunjuk baik bagi anak laki-laki maupun perempuan bahwa anak laki-laki lebih dihargai dalam kehidupan sosial.

Diskriminasi dalam dunia kerja ditunjukkan melalui pemberian posisi yang lebih berprestise kepada kaum laki-laki. Dunia kerja seringkali memberikan bayaran yang lebih tinggi pada kaum laki-laki dibanding pada kaum perempuan untuk pekerjaan yang sama, dan lebih mengunggulkan kaum laki-laki dalam pekerjaan yang melibatkan kompetisi antara 
laki-laki dan perempuan. Pada usia 40-an orang akan menyadari bahwa laki-laki merupakan kaum yang lebih disukai/lebih cocok dalam dunia bisnis dan profesi. Selain itu, media masa yang mengekspos sejarah prestasi kaum laki-laki dalam peperangan, seni, literatur, musik dan ilmu pengetahuan, serta menyoroti prestasi kaum laki-laki dalam segala bidang di masa kini. Terdapat kecenderungan media masa memberitakan prestasi kaum perempuan hanya dalam bidang seni, kecantikan dan fashion merupakan indikasi bahwa masyarakat lebih menghargai kaum laki-laki dibanding perempuan.

\section{Pengarusutamaan Gender (PUG)}

Pengarusutamaan gender (PUG) termasuk strategi yang di dalamnya mengembangkan dan

melaksanakan : (1) Program / kegiatan yang spesifik diperuntukkan bagi laki-laki atau perempuan; (2) Program/kegiatan yang strategik gender untuk memberdayakan laki-laki dan perempuan dalam rangka menghilangkan subordinasi, diskriminasi sehingga mereka dapat setara dalam pembangunan dan (3) Program/kegiatan untuk meningkatkan kapasitas (capacity building) dalam melaksanakan pengarusutamaan gender.

Tujuan akhir pengarusutamaan gender (PUG) adalah transformasi dari keadaan tidak setara antara perempuan dan laki-laki dlm hak dan kondisi sosial, menjadi setara bagi ke duanaya serta terpenuhinya kebutuhan praktis dan strategis gender. Strategi pengarusutamaan gender tidak sama dengan program pemberdayaan perempuan. Dalam melaksanakan pengarusutamaan gender diperlukan perubahan dalam agenda pembangunan, tujuan, dalam alokasi dana, strategi dan rencana aksi agar laki-laki dan perempuan dapat berpartisipasi dan mendapat manfaat yang sama dan adil dalam proses pembangunan (Yurni Satria). Pengarusutamaan gender adalah strategi yang digunakan untuk mengurangi kesenjangan antara penduduk laki-laki dan perempuan Indonesia dalam mengakses dan mendapatkan manfaat pembangunan, serta meningkatkan partisipasi dan mengontrol proses pembangunan. Selain itu juga merujuk pada pengintegrasian pengalaman, aspirasi, kebutuhan, dan permasalahan laki-laki dan perempuan ke dalam perencanaan, pelaksanaan, pemantauan dan evaluasi dari seluruh kebijakan, program, proyek dan kegiatan di berbagai bidang kehidupan dan pembangunan (Iklilah Muzayyanah, 2014). 


\section{Pengaruh Perilaku Pembedaan atau Pengarusutamaan Gender dari Sudut Pandang Psikologi}

Cepat atau lambat seorang anak akan merasakan atau mengetahui apakah ia (berdasarkan gendernya) anak yang diharapkan oleh orang tuanya, serta berdasarkan perubahan perlakuan yang diterimanya dari orang tuanya ataupun saudara-saudaranya. Hal ini akan tetap mempengaruhi sikapnya terhadap dirinya sendiri karena seseorang menginterpretasikan perilaku orang tuanya secara tepat atau keliru. Konsep diri seseorang juga akan dipengaruhi oleh perlakuan sikap saudara kandungnya terhadapnya. Jika pertentangan antar gender yang terjadi di dalam kelompok (sesama rekan sejawat) sangatlah kuat, maka reaksi seorang anak terhadap gendernya memiliki dampak yang kuat terhadap konsep dirinya.

Bahkan sebelum berakhirnya masa balita, tekanan sosial sudah muncul dalam diri anak-anak, yakni berupa tuntutan untuk berperilaku sesuai dengan gendernya dan memandang dirinya sebagaimana pandangan masyarakat terhadap orang-orang yang bergender sama dengannya. Dalam proses pembentukan kepribadiannya, kelompok budaya, yang dimulai dengan keluarga, kemudian berkembang menjadi rekan sebaya dan masyarakat, memberikan peluang dan dorongan kepada seseorang untuk belajar berperilaku yang seharusnya (sesuai dengan gendernya). Namun sebaliknya, kelompok tersebut menghambat / menghalanginya untuk belajar berperilaku seperti lawan jenisnya.

Kegagalan dalam mengatasi permasalahan dalam mengembangkan sikap yang sehat terhadap diri sendiri dan juga terhadap orang lain yang bergender sama dapat menyebabkan ketimpangan dalam penyesuaian diri dan sosial. Pada saat seorang anak mencapai usia 4 tahun, bahkan pada umumnya sebelum usia tersebut, ia akan menyadari bahwa di dunia ini tidak saja terdapat dua jenis manusia (laki-laki dan perempuan) tapi juga terdapat label-label tertentu yang diberikan kepada mereka. Kesadaran yang ia miliki biasanya didasarkan pada perbedaan dalam gaya / potongan rambut dan cara berpakaian. Pada waktu yang sama si anak juga menyadari label yang diberikan oleh orang lain kepadanya, sehingga hal ini akan membuatnya mampu mengidentifikasi dirinya dengan orang lain yang bergender sama dengannya. Pengetahuan akan hal di atas disertai dengan unsur emosional. Ketika seorang anak belajar bahwa orang (laki-laki dan perempuan) memiliki label yang berbeda, ia juga belajar bahwa label yang satu memiliki prestise yang lebih dibanding label yang lain. 
Karenanya pada usia dini seorang anak akan mulai memperhatikan berbagai hal yang ia lihat di sekitarnya.

Kesadaran ini semakin bertambah seiring dengan bertambahnya usia, karena dengan bertambahnya usia anak laki-laki dan perempuan akan mengambil jalannya masing-masing, sehingga menunjukkan perbedaan dalam minat dan juga menyesuaikan diri dengan pola perilaku yang berbeda. Mead menggambarkan dilema yang dimaksud dengan pernyataan:

"Jadi, kini kita memiliki paradoks memberikan kesempatan bagi kaum perempuan untuk memperoleh pendidikan seperti kaum laki-laki dan memberikan perempuan hak yang sama seperti yang dimiliki kaum laki-laki, kecuali dalam satu hal - hak untuk mengabdikan diri mereka pada tugas-tugas lain selain merawat rumah/pekerjaan rumah tangga. Terlepas dari apakah perempuan tersebut dapat memasak atau tidak, ibu yang baik atau kurang baik, ia harus menjadikan pekerjaan rumahtangga sebagai karier utamanya dan menjadikan kebutuhan dari suami dan anakanaknya sebagai sebagi kebutuhannya juga (khususnya bagi perempuan yang berbakat dan ambisius).”

Salah satu kesulitan terbesar bagi perempuan yang berpendidikan dalam menerima peran tradisional perempuan adalah adanya perubahan nilai. Lembaga sekolah mengembangkan nilai-nilai yang harus dikorbankan atau digantikan oleh kaum perempuan jika mereka ingin memperoleh kepuasan dari peran tradisional kaum perempuan. Beberapa masalah yang dihadapi oleh perempuan di Indonesia adalah ketika berdasarkan umur atau angka harapan hidup perempuan dan laki-laki terus meningkat, namun laki-laki masih jauh tertinggal dibandingkan dengan perempuan. Kurikulum Berbasis Gender menurut Emy Susanti Hendrarso: (1) pengadaan Pelajaran/kuliah gender, (2) pengembangan silabus dan materi pelajaran/kuliah yang berbasis gender, (3) mencegah masuknya materi yang berlawanan prinsip dengan keadilan dan kesetaraan gender, (4) memasukkan nilai gender pada semua mata-pelajaran/kuliah yang diajarkan, (5) mengetengahkan perspektif perempuan dan perspektif laki-laki dalam konteks keadilan gender dan (6) menjadikan prinsip keadilan gender sebagai basis atau orientasi dalam pengembangan manajemen, pola pengajaran, serta hubungan sosial di sekolah/universitas.

\section{Perlindungan Terhadap Anak}

Sistem perlindungan terhadap anak yang efektif mampu melindungi anak dari segala bentuk kekerasan, perlakuan salah, eksploitasi dan penelantaran yang mensyarakatkan 
adanya komponen-komponen yang saling terkait. Komponen-komponen ini meliputi beberapa hal, yaitu sistem kesejahteraan sosial bagi anak-anak dan keluarga, sistem peradilan yang sesuai dengan standar internasional, dan mekanisme untuk mendorong perilaku yang tepat dalam masyarakat. Selain itu, juga diperlukan kerangka hukum dan kebijakan yang mendukung serta sistem data dan informasi untuk perlindungan anak. Di tingkat masyarakat, berbagai komponen tersebut harus disatukan dalam rangkaian kesatuan pelayanan perlindungan anak yang mendorong kesejahteraan dan perlindungan anak dan meningkatkan kapasitas keluarga untuk memenuhi tanggung jawab mereka terhadap anaknya (Unicef Indonesia, 2012).

Menurut Undang-undang tentang Perlindungan Anak Nomor 23 Tahun 2002, perlindungan anak adalah segala kegiatan untuk menjamin dan melindungi anak dan hakhaknya agar tetap hidup, tumbuh, berkembang, dan berpartisipasi secara optimal sesuai dengan harkat dan martabat kemanusiaan, serta mendapat perlindungan dari kekerasan dan diskriminasi (Dewi Fauziah, 2010). Jaminan perlindungan hak asasi anak sesuai dengan nilai-nilai Pancasila dan tujuan Negara sebagaimana tercantum dalam Pembukaan UUD 1945. Anak-anak dapat mengalami kekerasan kapan saja dan di mana saja termasuk di dalam rumah, di sekolah, di tempat kerja, di jalanan, di tempat umum dan institusi seperti panti asuhan, lembaga pemasyarakatan dan sebagainya.

Kekerasan pada anak atau penderaan anak atau penganiayaan anak atau perlakuan salah terhadap anak merupakan terjemahan bebas dari child abuse, yaitu perbuatan semenamena orang yang seharusnya menjadi pelindung (guard) pada seorang anak (individu berusia kurang dari 18 tahun) secara fisik, seksual, dan emosional. Pengertian kekerasan Menurut UU perlindungan anak no 23 tahun 2003 dalam Pasal 3 UU PA adalah meliputi kekerasan fisik, psikis, seksual, dan penelantaran. UNICEF mendefinisikan bahwa kekerasan terhadap anak adalah "Semua bentuk perlakuan salah secara fisik dan/atau emosional, penganiayaan seksual, penelantaran, atau eksploitasi secara komersial atau lainnya yang mengakibatkan gangguan nyata ataupun potensial terhadap perkembangan, kesehatan, dan kelangsungan hidup anak ataupun terhadap martabatnya dalam konteks hubungan yang bertanggung jawab, kepercayaan, atau kekuasaan”. Menurut liunir Z, Upaya perlindungan yang dapat dilakukan berkaitan dengan kekerasan pada anak ini dapat dilakukan dengan pendekatan kesehatan pada masyarakat (public health), yaitu melalui usaha promotif, preventif, diagnosis, kuratif, dan rehabilitatif. Dua usaha yang pertama ditujukan bagi anak yang belum menjadi 
korban (non-victim) melalui kegiatan pendidikan masyarakat dengan tujuan utama menyadarkan masyarakat (public awarness) bahwa kekerasan pada anak merupakan penyakit masyarakat yang akan menghambat tumbuh kembang anak yang optimal, oleh karenanya harus dihapuskan. Sedangkan dua usaha terakhir ditujukan bagi anak yang telah menjadi korban (victim) dengan tujuan utama memberikan tata laksana korban secara menyeluruh (bolistic) meliputi aspek media, psikologis, sosial, termasuk di dalamnya upaya reintegrasi korban ke dalam lingkungannya semula. Upaya perlindungan tersebut dapat dilaksanakan oleh orang-orang yang profesional di bidangnya masing-masing di satu pihak dan media di pihak yang lain.

Undang-Undang Nomor 23 Tahun 2002 tentang Perlindungan Anak (U Perlindungan Anak) dalam Pasal 3 dijelaskan bahwa tujuan dari perlindungan anak adalah untuk menjamin terpenuhinya hak-hak anak agar dapat hidup, tumbuh berkembang, dan berpartisipasi secara optimal sesuai dengan harkat dan martabat kemanusiaan, serta mendapat perlindungan dari kekerasan dan diskriminasi, dengan begitu dapat terwujudnya anak Indonesia yang berkualitas, berakhlak mulia, dan sejahtera.

\section{Gambaran Administratif Masyarakat Kabupaten Lampung Tengah}

Kabupaten Lampung Tengah merupakan salah satu kabupaten yang terletak di tengah-tengah Provinsi Lampung yang memiliki wilayah keseluruhan, yakni $\pm 4789,82 \mathrm{Km}^{2}$ yang terbagi dalam 28 kecamatan. Jumlah penduduk Kabupaten Lampung Tengah pada tahun 2016 adalah 1.239.096 orang yang terdiri dari 630.962 orang atau sebesar 50,92\% penduduk berjenis kelamin laki-laki dan selebihnya yaitu 608.134 orang atau 49,07\% berjenis kelamin perempuan. Secara umum, sebagian besar penduduk yang tinggal di wilayah Kabupaten Lampung Tengah bermatapencaharian sebagai petani atau berada di sektor pertanian, yaitu 44,96\%. Berdasarkan hasil survey pada tahun 2015, total pencari kerja atau penduduk usia kerja sejumlah 3.750 orang yang didominasi oleh perempuan, yakni sejumlah 2.297 orang, sedangkan laki-laki sejumlah 1.533 orang. 
Berdasarkan partisipasi sekolah, dari 198.073 penduduk usia 19-24 tahun, sebagian besar sudah tidak sekolah lagi (2015), yakni sejumlah 130.403 orang (66\%), serta 65.553 orang $(33 \%)$ merupakan total penduduk yang masih sekolah. Sebagian besar dari mereka berada pada usia 13-18 tahun. Namun, terdapat penduduk yang tidak pernah mengenyam pendidikan sekolah, yakni sejumlah 2.177 orang $(1,1 \%)$ yang semuanya berjenis kelamin laki-laki dengan usia 19-24 tahun. Penduduk usia 19-24 tahun yang masih sekolah didominasi oleh mereka yang berjenis kelamin perempuan, sedangkan laki-laki mayoritas tidak sekolah lagi. Angka partisipasi sekolah paling besar berada pada kelompok umur 7-12 dan 13-15 tahun dengan angka masing-masing 98,6\% dan 96,5\% yang tergolong sangat tinggi. Pada kelompok umur 7-12, angka tersebut mengalami peningkatan yang stabil, sedangkan pada umur 13-15 mengalami penurunan sejak tahun 2012 hingga tahun 2015. Di sisi lain, angka partisipasi sekolah pada kelompok umur 16-18 meningkat pada tahun 2012 meskipun berada jauh di bawah kelompok usia 7-5 tahun.

Berdasarkan tingkat pendidikannya, menurut BPS Kabupaten Lampung Tengah, para pencari kerja di Kabupaten Lampung Tengah mayoritas berpendidikan SMA dan SMP yang masing-masing berjumlah 2.059 dan 1.040 orang. Usia kerja dengan pendidikan terakhir SD masih ada yakni sejumlah 148 orang yang didominasi oleh perempuan, sejumlah 99 orang (67\%), di mana 33\%nya merupakan pencari kerja berjenis kelamin lakilaki. Sebagian besar pencari kerja berjenis kelamin laki-laki (1.533 orang) berpendidikan SMA (1.085 orang) dan S1 (159 orang) dengan total 1.244 orang, sedangkan pencari kerja perempuan (2.197 orang) sebagian besar berpendidikan SMA (974), SMP (855), dengan total 1.829 orang. Pendidikan tinggi (S1) masih didominasi oleh laki-laki, sedangkan pendidikan SD banyak didominasi oleh perempuan.

Fasilitas mengenai pelayanan kesehatan di Kabupaten Lampung Tengah terdiri dari Rumah Sakit baik milik pemerintah maupun swasta, Rumah Bersalin, Puskesmas yang tersebar di beberapa desa, Posyandu, dan Klinik/Balai Kesehatan yang tersebar di berbagai kecamatan. Fasilitas kesehatan mayoritas merupakan Posyandu, yakni 307, kemudian 38 layanan puskesmas, 26 klinik, 8 Rumah Sakit, 1 rumah bersalin. Sedangkan mengenai jumlah dokter dalam beberapa sarana kesehatan di Lampung Tengah yang terdiri atas dokter spesialis, dokter umum dan dokter gigi, mayoritas merupakan dokter umum, yakni 121 orang, spesialis 85 orang, dan dokter gigi 25 orang. 


\section{Kasus Kekerasan Terhadap Perempuan dan Anak di Kabupaten Lampung Tengah}

Kebebasan dalam akses informasi yang didukung oleh media internet memudahkan masyarakat untuk mengakses segala informasi yang dibutuhkan dalam menjalankan hidupnya. Perkembangan teknologi ibarat pisau bermata dua di mana sisinya tergantung kepada pengguna dalam menentukan pilihannya. Teknologi dapat membantu manusia dalam menambah wawasan atau malahan menjerumuskannya kedalam kejahatan. Maraknya pemberitaan negatif di tengah-tengah masyarakat juga bisa menjadi ruang celah masyarakat untuk bertindak di luar hukum. Kasus-kasus kriminalitas yang diberitakan akan sampai ke telinga masyarakat, maka bukan hal yang mustahil jika sebagian besar dari masyarakat akan meniru perilaku tersebut.

Selain faktor informasi, semakin suatu daerah tersentuh dengan modernisasi maka juga akan berdampak pada meningkatnya biaya hidup sehari-hari. Masyarakat yang memiliki pendidikan, keterampilan dan kekayaan akan cenderung bertahan dalam memenuhi kebutuhan hidupnya. Namun, masyarakat yang berada di bawah garis kemiskinan dan tidak mempunyai keterampilan maka akan semakin terdesak. Dalam kondisi ini akan memperbesar peluang mereka untuk melakukan tindak kriminalitas dengan melampiaskannya kepada masyarakat lainnya. Paparan di atas adalah contoh dari beberapa hal yang menjadi alasan utama bagi terjadinya kasus kriminalitas kepada perempuan di Lampung Tengah yang terbagi menjadi 3 kategori, yaitu Kekerasan terhadap Perempuan, Kekerasan terhadap Anak, dan Kekerasan yang Dialami Perempuan sekaligus Anak.

Kekerasan Terhadap Perempuan Berdasarkan informasi yang didapatkan dari pihak Kejaksaan Negeri Lampung Tengah, Pusat Layanan Terpadu Pemberdayaan Perempuan dan Anak (P2TP2A), Bidang Perlindungan Perempuan dan Anak (BKBPPPA) dan Kepolisan Resort Lampung Tengah, terdapat beberapa data jenis dari kriminalitas yang telah terjadi yang menjadikan perempuan sebagai korban, yaitu kasus kekerasan dalam rumahtangga, dan kasus Narkotika yang Melibatkan Perempuan. Sedangkan kasus kekerasan terhadap anak lebih banyak ditemukan berupa kejahatan seksual seperti pencabulan dan pemerkosaan dan kekerasan fisik. 
Kasus kekerasan perempuan tersebut sebagian besar terjadi di sebagian daerah tertentu atau tersebar di kecamatan-kecamatan tertentu saja. Ironinya adalah kecamatan yang memiliki tingkat kerawanan kekerasan terhadap perempuan terjadi di daerah yang menjadi pusat kegiatan masyarakat, perekonomian dan politik di wilayah ini.

$\checkmark$ Kekerasan terhadap Anak Kebebasan dalam akses informasi yang didukung oleh maraknya penggunaan media internet memudahkan masyarakat untuk mengakses segala informasi yang dibutuhkan. Perkembangan teknologi ibarat pisau bermata dua, tergantung kepada pengguna dalam menentukan pilihannya. Teknologi dapat membantu manusia dalam menambah wawasan atau malahan menjerumuskannya kedalam kejahatan. Maraknya pemberitaan negatif di tengah-tengah masyarakat juga bisa menjadi ruang celah masyarakat untuk bertindak di luar hukum. Kasus-kasus kriminalitas yang diberitakan akan sampai ke telinga masyarakat, maka bukan hal yang musathil sebagian dari masyarakat akan meniru hal tersebut.

Selain faktor informasi, semakin suatu daerah tersentuh dengan modernisasi maka juga akan berdampak pada meningkatnya biaya hidup sehari-hari. Masyarakat yang memiliki pendidikan, keterampilan dan kekayaan akan cenderung bertahan dalam memenuhi kebutuhan hidupnya. Namun, masyarakat yang berada di bawah garis kemiskinan dan tidak mempunyai keterampilan maka akan semakin terdesak. Dari data yang telah dihimpun, terdapat 1414 kasus kekerasan yang dialami oleh anak atau bisa disebut juga kasus kekerasan yang berkaitan dengan anak di mana anak tidak hanya menjadi korban kekerasan, namun juga menjadi pelaku dari kejahatan itu sendiri. Dari 1414 kasus, kekerasan yang berkaitan dengan anak dikategorikan menjadi 4 hal, yaitu Anak Berhadapan dengan Hukum (168 kasus), Anak Terlibat Narkoba (38 kasus), Anak Korban Kekerasan (783), Anak Disabilitas (425 kasus).

Jumlah anak korban kekerasan fisik adalah 783 kasus yang mendominasi kasus kekerasan terkait anak, hingga mencapai 55\% . Namun, dalam penanganannya, kasus kekerasan terhadap anak hanya terdapat beberapa kasus yang sampai ditindaklanjuti ke ranah hukum, yakni 8 kasus (1\%) yang merupakan jumlah mereka yang mendapat hukuman atas tindak pidana yang telah dilakukannya. Sebagian besar masyarakat masih memiliki rasa takut untuk melaporkan kasus kekerasan yang dialami oleh anak-anak 
yang berada di sekitarnya. Kekerasan ini jelas menimbulkan trauma bagi anak, terutama gangguan secara psikis.

Dari kasus kekerasan terkait anak, anak terlibat narkoba sebanyak 38 kasus (2,7\%) yang terdeteksi karena sangat dimungkinkan masih banyak yang belum terungkap oleh hukum. Anak-anak dengan disabilitas memiliki permasalahan sendiri sehingga berbeda dalam hal penanganannya. Dari 1414 kasus, anak yang menderita disabilitas sejumlah 426 orang yang berarti 30\%nya. Anak-anak ini dianggap lebih rentan untuk mengalami kekerasan sehingga dalam hal memberdayakan anak, maka semua anak memilik hak yang diatur undang-undang dan wajib dilaksanakan dengan baik dan tepat serta perlakuan khusus di mana mereka juga dilibatkan dalam kehidupan bermasyarakat dan mendapatkan sosialisasi yang sempurna.

$\checkmark$ Kekerasan terhadap Perempuan dan Anak berupa Pencurian dengan Kekerasan Pada tahun 2016, terdapat 71 kasus pencurian dengan tindak kekerasan di Kabupaten Lampung Tengah. Dari jumlah semua kasus, sekitar 42 kasus korbannya adalah wanita dan anak-anak. Dalam hal ini, tercatat memiliki wilayah tertentu dengan tingkat pengaduan yang terbanyak yaitu 21 kasus atau terpusat. Jika melihat dari konsentrasi kejadian kasus-kasus tersebut maka didominasi terjadi pada daerah yang dilalui jalan arteri primer, daerah yang merupakan pusat perekonomian dan kegiatan masyarakat sehingga masyarakat dari segala penjuru akan berkumpul ke dua daerah ini. sehingga ada baiknya pemerintah untuk memperketat penjagaan pada daerah-daerah yang relatif sepi dari kendaraan yang melalui jalan tersebut.

\section{Analisis Studi Pengarusutamaan Gender dan Perlindungan Anak di Bidang Pendidikan dan Pelayanan Kesehatan}

Dalam mengkaji pelaksanaan dari Pengarustamaan Gender (PUG) dalam bidang pendidikan di Kabupaten Lampung Tengah, yang secara khusus memfokuskan pengamatan pada Dinas Pendidikan, terdapat beberapa hal pokok yang bisa dilihat dan menjadi bahan analisis, yaitu:

\section{Fokus Peraturan \& Perundang-undangan (Komitmen Politik) dalam hal Pengarusutamaan Gender dan Perlindungan Anak dalam Bidang Pendidikan}


Terkait PUG dalam pembangunan pendidikan di Kabupaten Lampung Tengah, suatu informasi ilmiah menunjukkan bahwa Dinas Pendidikan telah memiliki dukungan kebijakan/komitmen dalam bentuk Keputusan Bupati Lampung Tengah Nomor 160/KPTS/D.1/2011 tentang Kelompok Kerja Pengarusutamaan Gender (Pokja PUG) Bidang Pendidikan Kabupaten Lampung Tengah tahun 2011-2015. Saat diterbitkan, surat keputusan ini seharusnya menjadi suatu bentuk dukungan kebijakan/komitmen yang nyata dari pemerintah daerah terhadap pelaksanaan Program PUG di Kabupaten Lampung Tengah. Namun, keberadaan dukungan kebijakan ini belum dibarengi dengan dukungan informal terhadap pelaksanaan PUG ini misalnya: dalam bentuk pembahasan masalah gender oleh pimpinan institusi dalam kegiatan-kegiatan di lingkungan dinas pendidikan. Hal ini telah dibuktikan dengan tidak adanya implementasi dari pihak-pihak terkait sehingga sudah lima tahun tidak ada perkembangan dari kelompok kerja tersebut dalam bentuk kegiatan atau program kerja yang nyata.

Sedangkan untuk perlindungan anak, Pemerintah Daerah Kabupaten Lampung Tengah belum menerbitkan peraturan dalam bentuk apapun untuk menunjukkan komitmennya dalam perlindungan anak di mana anak-anak di kabupaten ini masih banyak yang mengalami kekerasan fisik, termasuk kekerasan seksual di dalamnya yang bahkan mencapai ribuan. Begitu pula dengan anak-anak lainnya yang berhadapan dengan hukum di mana banyak anak, terutama yang tidak bersekolah atau melanjutkan sekolah hingga SMA yang melakukan kejahatan seperti menyalahgunakan narkoba dengan menjual hingga memakai, dan melakukan pencurian denagn kekerasan.

\section{Fokus dalam Penyusunan Kebijakan, Program dan Kegiatan}

Dalam menyusun program kerja, Dinas Pendidikan menyesuaikan dengan anggaran yang telah ditetapkan oleh pemerintah daerah, bukan berdasarkan gender tertentu. Mencermati rencana program dan kegiatan Dinas Pendidikan sebagai salah satu SKPD Pemerintah Kabupaten Lampung Tengah, secara umum masih bersifat netral gender. Hal ini disebabkan oleh tidak ada satupun di antaranya yang mengintegrasikan isu-isu gender ke dalam kebijakan, strategi, program dan kegiatan yang telah dilakukan maupun yang direncanakan untuk tahun berikutnya. Program-program tersebut belum berpihak pada salah satu kelompok jenis kelamin tertentu, baik laki-laki atau perempuan yang memang memerlukan penanganan karena ada masalah pada kelompok tersebut. Hal ini 
kemungkinan besar dikarenakan belum terdapat berbagai data terpilah yang menggambarkan kondisi laki-laki dan perempuan dalam bidang ini sehingga isu dan permasalahan gender di bidang pendidikan belum teridentifikasi secara jelas. Isu-isu gender seolah belum terlihat sehingga belum dianggap signifikan sebagai pertimbangan dalam mengambil atau memutuskan kebijakan tertentu.

\section{Sumberdaya Manusia, Pendanaan dan Prasarana yang Memadai}

Sumberdaya manusia yang dimiliki Pemerintah Kabupaten Lampung Tengah untuk mengimplementasikan PUG, khususnya bidang pendidikan masih relatif rendah. Pengetahuan pejabat perencana dan pengambil keputusan tentang Keadilan dan Kesetaraan Gender tidak bisa dianggap mumpuni dalam memahami konsep gender dan perlindungan anak apalagi untuk menganggapnya sebagai pertimbangan penting dalam merumuskan suatu program kerja. Dinas Pendidikan belum memiliki Sumberdaya Manusia yang memahami PUG, sehingga belum dapat menjadi focal point gender.

Sejak tahun 2002 telah diadakan pelatihan PUG dalam pembangunan daerah khususnya untuk pejabat di bagian perencanaan program/kegiatan dengan dana Project ADB. Kegiatan tersebut telah berlanjut pada tahun-tahun berikutnya dengan jenis pelatihan dan kegiatan yang lain untuk mendukung pelaksanaan pengarusutamaan gender dalam pembangunan daerah, antara lain: Pelatihan Analisis Gender dan Monitoring Evaluasi Program Kebijakan Pembangunan bagi Aparatur Perencanaan, dan Pelatihan Penyusunan Anggaran Responsif Gender bagi Aparatur Perencanaan Pembangunan Kabupaten Lampung Tengah. Pelatihan pelatihan tersebut sangat mendukung pada peningkatan kualitas SDM apatur pemerintah daerah setempat. Namun kenyataannya, pejabat yang terbaru atau sedang menjabat tidak mengetahui mengenai pelatihan ini sehingga belum memiliki pengetahuan yang cukup mengenai gender dan pengarusutamaannya.

\section{Ketersediaan dan pemanfaatan data agregat berdasarkan jenis kelamin}

Berbagai data yang penting yang telah dikumpulkan oleh Dinas Pendidikan, tidak ada satupun yang terpilah berdasarkan jenis kelamin, meskipun terdapat data yang dipilah berdasarkan usia. Data terpilah berguna untuk menghasilkan data statistik serta indikator pendidikan yang berwawasan gender agar permasalahan gender tidak terjadi atau tidak membesar sehingga para perencana dapat memahami adanya perbedaan pengalaman, 
aspirasi, dan permasalahan antara perempuan dan laki-laki. Namun pada kenyataannya tidak disajikan data secara terpilah gender, baik rata-rata lama sekolah, Angka Partisipasi Murni (APM), Angka Partisipasi Kerja (APK), dan angka melek huruf yang masih disajikan secara umum.

\section{Bidang Kesehatan}

Dalam bidang kesehatan, studi ini mengamati beberapa hal yang terdapat pada Dinas Kesehatan Kabupaten Lampung Tengah yang memiliki wewenang dalam memanajemen bidang ini, yaitu:

\section{Fokus Peraturan \& Perundang-undangan (Komitmen Politik) dalam hal Pengarusutamaan Gender dan perlindungan anak dalam bidang kesehatan}

Terkait PUG dalam pembangunan kesehatan di Kabupaten Lampung Tengah, data menunjukkan bahwa Dinas Kesehatan tidak memiliki dukungan kebijakan/komitmen dalam bentuk Keputusan Bupati Lampung Tengah atau Surat Keterangan yang secara khusus menginstruksikan atau memberikan payung hukum yang tegas dalam PUG dan Perlindungan Anak. Komitmen politik (political will), dukungan kebijakan pengarusutamaan gender di Kabupaten Lampung Tengah dapat ditelusuri dengan merujuk pada Perda/Surat Keputusan/Surat Edaran yang dikeluarkan oleh Bupati dan pimpinan tertinggi di setiap SKPD, terutama Dinas Kesehatan. Hal tersebut menunjukkan bahwa tidak adanya komitmen dari pimpinan tertinggi terhadap pelaksanaan PUG dalam pembangunan kesehatan di Kabupaten Lampung Tengah. Pelayanan kesehatan yang terpadu bagi ibu dan anak sebagai bagian penting dari keberlangsungan suatu pembangunan sangat membutuhkan penegasan melalui peraturan pemerintah daerah agar program penanganan dapat dibentuk dan dijalankan oleh Dinas kesehatan.

\section{Fokus dalam Penyusunan Kebijakan, Program Dan Kegiatan}

Mencermati rencana program dan kegiatan Dinas Kesehatan sebagai salah satu SKPD dari Pemerintah Kabupaten Lampung Tengah, secara umum masih bersifat netral gender. Jika diamati, Hal masih banyak di antaranya yang belum mengintegrasikan isu-isu gender ke dalam kebijakan, strategi, program dan kegiatan yang telah dilakukan maupun yang 
direncanakan untuk tahun berikutnya. Misalnya saja mengenai Program Peningkatan Keselamatan Ibu Melahirkan dan Anak yang terbagi menjadi tiga program khusus, yaitu Pelayanan Kesehatan Ibu dan Anak, Pelayanan Kesehatan Reproduksi Remaja, dan Pelatihan dan Pendidikan Perawatan Kesehatan Usila (Usia Lanjut). Program-program tersebut memang sudah berpihak pada salah satu kelompok jenis kelamin tertentu, yaitu perempuan yang memang memerlukan penanganan karena kerentanan fisik yang dimilikinya, namun belum berbasis gender. Selain itu, isu dan permasalahan gender di bidang kesehatan belum teridentifikasi secara jelas karena data-data tersebut belum mengalami analisis gender atau belum dianggap signifikan sebagai pertimbangan perencana dalam mengambil atau memutuskan kebijakan tertentu.

\section{Sumberdaya Manusia, Pendanaan dan Prasarana yang Memadai}

Dinas kesehatan belum memiliki sumberdaya yang bisa disebut memadai dalam mengimplementasikan PUG. Selain disebabkan rendahnya pengetahuan pejabat perencana dan pengambil keputusan tentang keadilan dan kesetaraan gender dengan belum memahami konsep gender dan perlindungan anak yang tepat, dari segi pendanaan juga belum ada dukungan anggaran yang responsif gender, baik dari APBD maupun hibah khusus. Sementara itu, dari sarana dan prasarana, belum terdapat Kelompok Kerja yang dibentuk atau Tim Pokja PUG yang memiliki fungsi praktis dan strategis bagi percepatan untuk mewujudkan pembangunan daerah yang responsif gender. Perempuan dan anak dianggap sebagai kelompok rentan namun belum mendapatkan perhatian khusus secara utuh.

\section{Ketersediaan dan Pemanfaatan Data Agregat berdasarkan Jenis Kelamin}

Mekanisme pendataan data terpilah menurut jenis kelamin dan usia dilakukan oleh Dinas Kesehatan, terutama dalam level Puskesmas-puskesmas yang terdapat di kecamatan-kecamatan beserta desa-desa yang jaraknya cenderung lebih dekat dengan masyarakat setempat. Data-data tersebut mengenai Kepesertaan dan Pelayanan Kesehatan Jaminan Kesehatan Nasional (JKN) berupa layanan BPJS dan Jamkesmas. Namun, hal 
tersebut belum sepenuhnya disadari bahwa data tersebut dapat digunakan sebagai data pembuka wawasan masalah kesenjangan gender dalam bidang kepegawaian dan kesehatan masyarakat secara umum. Selain itu data terpilah juga mengenai data kunjungan masyarakat ke puskesmas terdekat serta gizi buruk bagi bayi dan balita serta perkembangan Angka Kematian Ibu dan Bayi baru lahir (AKI dan AKB).

\section{KESIMPULAN}

Kondisi mengenai gender dan perlindungan anak jika ditinjau secara akademis dan perundangan? Tidak adanya diskriminasi antara perempuan dan laki-laki, dengan demikian mereka memiliki akses, kesempatan berpartisipasi, dan kontrol atas pembangunan serta memperoleh manfaat yang setara dan adil dari pembangunan. Orangtua harus berusaha membuat anak merasa lebih aman, tetap aman, dan mengurangi adanya risiko bahaya kekerasan fisik dan mental yang bisa saja terjadi kepada anak-anak.

Perempuan belum sepenuhnya memahami ketika mereka mengalami kekerasan secara mental karena hanya mengetahui bahwa kekerasan hanya berupa fisik, laki-laki belum memiliki motivasi untuk memiliki pendidikan yang lebih tinggi, masih banyak orangtua yang belum memiliki pengetahuan mengenai pola asuh terhadap anak yang tepat, serta masih ada pelayanan kesehatan yang belum memiliki standar pelayanan bagi anak-anak sehingga hak anak dalam kesehatan belum sepenuhnya terpenuhi.

Belum adanya komitmen politik yang seharusnya dituangkan dalam sebuah payung hukum yang jelas dalam implementasi Pengarusutamaan Gender dan Perlindungan Anak di Kabupaten Lampung Tengah karena masih sebatas wacana atau harapan. Dalam bidang pendidikan, payung hukum PUG berupa SK Bupati tentang Kelompok Kerja PUG yang belum terlihat perannya secara nyata. Sedangkan bidang kesehatan belum memiliki peraturan apapun yang berkaitan dengan PUG dan Anak.

Dilihat dari penyusunan kebijakan, program dan kegiatan, bidang pendidikan dikategorikan netral gender begitu pula dengan bidang kesehatan, namun jika bidang kesehatan mencantumkan program Kesehatan Ibu dan Anak berbasis gender, maka selangkah lagi akan memasuki framework yang responsif gender dan anak. Ketersediaan sumberdaya manusia yang responsif gender tidak dimiliki oleh kedua bidang ini meskipun dari pendanaan bidang kesehatan menyediakan dana 0,002\% dari total plafon Anggaran 
Dinas Kesehatan bagi program yang berkaitan dengan perempuan dan anak. Sedangkan, Dinas Pendidikan tidak memiliki program kerja berdasarkan gender dan anak.

\section{DAFTAR PUSTAKA}

BPS Kabupaten Lampung Tengah, 2015

Buku Data Terpilah Gender, 2013, Sukabumi: Pemerintah Kota Sukabumi

Emy Susanti Hendrarso mengenai Pengarusutamaan Gender dalam Pendidikan \& Strategi Pendidikan Gender

Fauziah, Dewi, Perlindungan Anak Korban Kekerasan dalam Keluarga, 2010, Yogyakarta: UIN Sunan Kalijaga

Herien Puspitawati mengenai Persepsi Peran Gender terhadap Pekerjaan Domestik dan Publik pada Mahasiswa IPB

Hidayat, Rahmat Dudung, Pengaruh_Sex_Determinants, Bandung: FPBS UPI

Iklilah Muzayyanah Df., M.Si Dalam Pengarusutamaan Gender Di Indonesia Dipresentasikan Pada Workshop Pengarusutamaan Gender Dan Anak Di Perguruan Tinggi Agama Islam) Hotel T, 1 Oktober 2014

Muzayyanah, Iklilah, Df., M.Si, Pengarusutamaan Gender di Indonesia yang diipresentasikan pada Workshop Pengarusutamaan Gender dan Anak di Perguruan Tinggi Agama Islam) 2014, Hotel T

Puspitawati, Herien, Persepsi Peran Gender terhadap Pekerjaan Domestik dan Publik pada Mahasiswa IPB, Bogor

Ringkasan Kajian UNICEF Indonesia Oktober 2012

Undang-Undang Nomor 23 Tahun 2002, Tentang Perlindungan Anak, Bandung: Citra Umbara 
Yurni Satria Dalam Mengenali Dan Memahami Pengarusutamaan Gender (PUG) Dalam Pembangunan

Z Liunir, Kekerasan Terhadap Anak; Permasalahan Dan Pemecahannya Child Abuse : Problems And Solutions

Aprilina. Wahyu Diah, Pengarusutamaan Gender dalam Pembangunan Kualitas Sumber Daya Manusia (Studi Analisis Isi UU Nomor 20 tahun 2003 tentang Sistem Pendidikan Nasional). 2015. Yogyakrta: Universitas Gadjah Mada.

Marpaung, Putri C. Kinerja Biro Pemberdayaan Perempuan Setdaprovsu dalam Implementasi Pengarusutamaan Gender di Provinsi Sumatera Utara. 2011. Sumatera Utara: USU 